УДК 336.025: 339.9: 330.34

DOI: https://doi.org/10.37320/2415-3583/11.14

Котковський В.С.

доктор економічних наук, доцент, доцент кафедри соціально-політичних та економічних дисциплін, Криворізький факультет Національного університету «Одеська юридична академія» ORCID: https://orcid.org/0000-0001-5150-1751

Дробчак А.Л. старший викладач кафедри соціально-політичних та економічних дисциплін, Криворізький факультет Національного університету "Одеська юридична академія" ORCID: https://orcid.org/0000-0003-4262-1561

Лескова-Годлевська Ю.К. директор,

Криворізький юридичний коледж Національного університету «Одеська юридична академія» ORCID: https://orcid.org/0000-0001-9646-4755

\title{
ОЦІНЮВАННЯ РІВНЯ ФІНАНСОВОЇ БЕЗПЕКИ УКРАЇНИ В УМОВАХ ФІНАНСОВОЇ ГЛОБАЛІЗАЦІї
}

\begin{abstract}
Метою статті є виконання комплексного оцінювання рівня фінансової безпеки Украӥни та аналіз ї̈ окремих показників. Проаналізовано динаміку інтегральних показників окремих складових елементів фінансової безпеки України. Виявлено невідповідність даних очінювання фінансової безпеки України та ї̈ фактичного рівня. Також встановлено, шо глобалізаиійні проиеси зачіпають усі складники фінансової безпеки держсви, створюючи загрози для розвитку національної економіки. Напрямом удосконалення методичних підходів до оцінювання рівня фінансової безпеки України є додавання індикатора ризиків фінансової поведінки населення, пов'язаних із заощзадженнями населення та його операціями на кредитному і валютному ринках, а також вдосконалення процесу очінювання фінансової безпеки Украӥни в умовах глобалізації фінансових ринків.
\end{abstract}

Ключові слова: глобалізачія, фінансова безпека, економічна безпека, банківська безпека, бюджетна безпека, валютна безпека, грошово-кредитна безпека, боргова безпека, безпека небанківського фінансового сектору, інтегральний показник.

Постановка проблеми. Важливим процесом розвитку економіки XXI ст. є глобалізація, темпи якої набувають обороти за останні десятиліття завдяки досягненням у сферах технології, науки, зв'язку, промисловості тощо. Поняття глобалізації часто використовується не тільки у вищеназваних сферах, а й у фінансово-економічній, оскільки остання несе в собі як нові можливості для людства, так і нові загрози. Зокрема, процес глобалізації стосується дотриманням принципів національного суверенітету, розвитком сучасного суспільства, фінансовими можливостями держави, а також пов'язаний із загрозами національній безпеці держави, в т. ч. фінансовій.

Оцінювання кризових ситуацій у фінансовій сфері пов'язане з виявленням та аналізом реальних, а також потенційних загроз фінансовій безпеці держави. Для формування системи моніторингу таких загроз, що враховує як характер функціонування економічного механізму національної економіки, так і перманентно мінливі зовнішні умови, необхідний загальновизнаний методологічний підхід до дослідження індикаторів фінансової безпеки, покликаних достовірно відображати наявні та потенційні загрози. Наявні дослідження у сфері індикативної оцінки фінансової безпеки України часто суб'єктивні та еклектичні. Тому актуальним $є$ дослідження і здійснення методичних підходів до ідентифікації та оцінювання індикаторів фінансової безпеки 3 тим, щоб визначити характер досягнень та наявну проблемну площину.

Аналіз останніх досліджень i публікацій. Проблеми фінансової безпеки дедалі частіше привертають увагу вітчизняних і закордонних науковців. Питанням виявлення сутності та виокремлення ключових складників фінансової безпеки присвячені наукові дослідження таких вітчизняних учених, як О.О. Гудзовата [4], А.В. Кулінська [7], О.Л. Кузенко [8], О.Ю. Мелих [9], а також низки зарубіжних науковців, серед яких В. Аллен, Г. Вуд, Ш. Бланкарт, Г. Костер, Дж. Хейкер, Ф. Рем, М. Шлезінгер та ін. Найбільш повно в роботах названих авторів аналізуються механізми формування і забезпечення фінансової безпеки, ііі поточний стан, проблеми і шляхи розв'язання. Проте у вітчизняній науковій літературі майже не обговорюються методичні підходи до вибору індикаторів фінансової безпеки України. 
Необхідно констатувати, що перші спроби оцінити стан фінансової безпеки України належать Н.В. Винниченко, О.М. Есманову [18], В.М. Мирончук, Ю.М. Паночишину [10], які поставили за мету обгрунтувати необхідність удосконалення науково-методичних підходів до оцінки економічної і фінансової безпеки України. Вони оцінили макроекономічну, боргову, бюджетну, грошово-кредитну та валютну безпеку України. Однак до дослідження не попали банківська безпека та безпека небанківського фінансового сектору, а також період оцінки охопив 2007-2012 роки. Слід звернути увагу на працю А.В. Кулінської [7], в якій досліджено теоретико-методологічні засади державного управління фінансовою складовою частиною економічної безпеки національної економіки України. Авторка дослідила причинно-наслідкові зв'язки між складниками бюджетної безпеки національної економіки України, визначила рівень боргового навантаження на стан економіки України та фактори забезпечення інвестиційної безпеки економіки України за 2010-2016 роки. Проте спостерігаємо відсутність застосування наявних методик розрахунку рівня фінансової безпеки України. Також заслуговує на увагу визначення О.Ю. Мелих системи індикаторів фінансової безпеки України та дослідження впливу загроз на соціально-економічний розвиток держави [9]. Знову ж таки констатуємо відсутність розрахунків інтегральних показників окремих складників фінансової безпеки України. I тільки дослідженнями I.I. Рекуненко [14] визначено основні причини та коливання рівня фінансової безпеки України за секторами, розраховано відповідні значення субіндексів економічної безпеки та значення інтегрального показника фінансової безпеки України за 2013-2018 роки та запропоновано заходи щодо покращення поточного рівня фінансової безпеки.

Отже, доходимо висновку, що досі відсутне комплексне оцінювання рівня фінансової безпеки України та аналіз ії показників, недостатньо висвітленими $\epsilon$ і питання, які стосуються алгоритму діагностики та регулювання стану фінансової безпеки держави в умовах глобалізації. Тому ставимо за мету оцінити рівень фінансової безпеки України за 2014-2018 роки, запропонувати використання індикатора ризиків фінансової поведінки населення під час визначення загального інтегрального показника фінансової безпеки України та здійснити прогноз останнього на 2019-2020 роки.

Виклад основного матеріалу. Фінансова безпека $є$ ключовою складовою частиною не лише економічної, а й національної безпеки країни, а на думку Дж. Хейкера, Ф. Рема та М. Шлезінгера [3], ще й безпеки кожної людини. На відміну від макроекономічної безпеки, фінансова безпека не є однорідною - вона складається із груп множин, серед яких: банківська, бюджетна, грошово-кредитна, валютна, боргова, безпека небанківського фінансового сектору.

Дослідженнями доведено, що у вітчизняній практиці для оцінювання стану фінансової безпеки України застосовуються Методичні рекомендації Міністерства економічного розвитку та торгівлі України, а також методика за індексом глобальної конкурентоспроможності. Метою зазначених методик $\epsilon$ визначення рівня економічної безпеки держави, основним складовим елементом якої є фінансова безпека та яка займає провідне місце серед усіх складників економічної безпеки держави.

У Методичних рекомендаціях, затверджених наказом № 1277 Міністерства економічного розвитку і торгівлі України від 29.10.2013 р., визначається перелік основних індикаторів стану фінансової безпеки України, їхні порогові значення, а також алгоритм розрахунку інтегрального індексу фінансової безпеки. Таких індикаторів (показників) стану фінансової безпеки методичними рекомендаціями передбачено 32. Розрахунок інтегрального індексу фінансової безпеки здійснюється за допомогою вагових коефіцієнтів, які визначено шляхом експертного оцінювання [11].

Для кожного індикатора складників стану економічної безпеки України розроблені характеристичні значення, які, зокрема, і визначають рівень фінансової безпеки. Діапазон характеристичних значень кожного показника (індикатора) вимірюється від 0 до 1 (або від 0 до 100 відсотків) та поділяється на п'ять інтервалів [11]:

- критичний рівень - 0,2, або $20 \%$ оптимального значення;

- небезпечний рівень - 0,4, або 40\% оптимального значення;

- незадовільний рівень - 0,6, або $60 \%$ оптимального значення;

- задовільний рівень - 0,8, або $80 \%$ оптимального значення;

- оптимальний рівень - 1 , тобто дорівнює оптимальному значенню.

Присвоєння характеристичних значень певній величині індикатора складника економічної безпеки здійснюється за допомогою таких методів:

- аналогового методу (оптимальними вважаються значення індикатора в країнах, які визнані еталоном у цій сфері);

- законодавчо-нормативного критерію (критичний або оптимальний рівень визначається відповідно до граничного рівня, закріпленого в національному законодавстві чи профільними міжнародними організаціями);

- експертної оцінки.

Щорічно Україна бере участь у дослідженнях рейтингу міжнародної конкурентоспроможності, які проводить Всесвітній економічний форум 
(ВЕФ). Кожного року ВЕФ ранжує країни за індексом глобальної конкурентоспроможності, який оцінюється на основі певних параметрів, таких як: якість інституцій, інфраструктура, макроекономічна стабільність, охорона здоров'я і початкова освіта, вища освіта і професійна підготовка, ефективність ринку товарів і послуг, ефективність ринку праці, розвинутість фінансового ринку, технологічний рівень, розмір ринку, відповідність бізнесу сучасним вимогам, інноваційний потенціал. Як бачимо, до розрахунку включено 12 параметрів, які характеризують конкурентоспроможність країн $[17$, с. 71$]$.

Необхідно констатувати, що вагомий внесок у розроблення методологічних засад оцінювання рівня фінансової безпеки зробили Методичні рекомендації фахівців Національного інституту проблем міжнародної безпеки РНБО України 2003 р. Ця методика передбачала розрахунок 22 показників економічної безпеки та їх порівняння з установленими пороговими значеннями. Стосовно запропонованого переліку показників слід відзначити, що він відповідав актуальним соціально-політичним та економічним тенденціям вітчизняного суспільства на момент розроблення рекомендацій, тобто на початку 2000-х років [6, с. 23]. Розрахунок інтегрального показника рівня як економічної, так і фінансової безпеки Методичними рекомендаціями не передбачений. Крім того, існування Національного інституту проблем міжнародної безпеки РНБО України припинено.

Отже, нині для розрахунку інтегрального показника рівня фінансової безпеки України використовуються Методичні рекомендації, затверджені наказом Міністерства економічного розвитку i торгівлі України. Розвиток методології оцінювання фінансової безпеки України має передбачати розроблення методичних підходів, які дають змогу надати грунтовну оцінку сучасним детермінантам фінансової безпеки держави через відповідні індикатори кількісного та якісного характеру.

Використовуючи вимоги Методичних рекомендацій Міністерства економічного розвитку та торгівлі України, проведемо оцінювання фінансової безпеки як вагомої складової частини національної безпеки України. 3 урахуванням нормованих значень показників та їхніх вагових коефіцієнтів, які в методичних рекомендаціях визначені шляхом експертного оцінювання та не потребують додаткового розрахунку, було сформовано інтегральні показники кожного елемента фінансової безпеки (табл. 1).

Згідно з даними табл. 1, у період 2014-2018 років значення інтегрального індикатора банківської безпеки України мало тенденцію до збільшення, тобто спостерігалося підвищення рівня небезпеки банківської системи з незадовільного у 2014 році $(0,29)$ до критичного у 2018 році $(0,38)$. Зазначене насамперед було зумовлене збільшенням частки простроченої заборгованості за кредитами на $31 \%$ у 2018 році проти 2014 року, банківських кредитів та депозитів в іноземній валюті - на 16,6\%, частки іноземного капіталу у статутному капіталі банків - на 2 відсоткові пункти, зростанням частки п'яти найбільших банків у сукупних активах банківської системи на 5\%.

Найвище значення інтегрального показника безпеки небанківського фінансового ринку спостерігалося у 2014 році і становило 0,46 - «небезпечний рівень», а найнижче - у 2017 році (0,30 «критичний рівень»). Така ситуація сформувалася за рахунок зниження рівня капіталізації лістингових компаній щодо ВВП на 84\%, а також приростом частки надходжень страхових премій трьох найбільших страхових компаній у загальному обсязі надходжень страхових премій на 4,8 відсоткових пункти.

Рівень бюджетної безпеки визначається порівнянням фактичних значень індикаторів 3 пороговими, які розроблялись 3 урахуванням світового досвіду та напрацювань вітчизняних вчених. Розрахунки рівня бюджетної безпеки України за кожним іiі індикатором свідчать про іiі критичний стан протягом 2014-2016 рр., в наступні роки - незадовільний стан, що позитивно впливає на загальний стан фінансової системи України [18, с. 49]. У 2017-2018 рр. індикатор бюджетної безпеки зріс з 0,61 до 0,67 відповідно.

Таблиця 1 - Динаміка інтегральних показників складників фінансової безпеки за методичними рекомендаціями Міністерства економічного розвитку та торгівлі України за 2014-2018 роки

\begin{tabular}{|l|l|l|l|l|l|}
\hline \multicolumn{1}{|c|}{ Інтегральний індикатор } & \multicolumn{1}{|c|}{$\mathbf{2 0 1 4}$} & $\mathbf{2 0 1 5}$ & $\mathbf{2 0 1 6}$ & $\mathbf{2 0 1 7}$ & $\mathbf{2 0 1 8}$ \\
\hline Банківська безпека & 0,29 & 0,19 & 0,23 & 0,35 & 0,38 \\
\hline Безпека небанківського фінансового ринку & 0,46 & 0,34 & 0,32 & 0,30 & 0,31 \\
\hline Бюджетна безпека & 0,47 & 0,48 & 0,47 & 0,61 & 0,67 \\
\hline Грошово-кредитна безпека & 0,53 & 0,34 & 0,51 & 0,48 & 0,49 \\
\hline Валютна безпека & 0,26 & 0,36 & 0,38 & 0,40 & 0,42 \\
\hline Боргова безпека & 0,04 & 0,03 & 0,15 & 0,20 & 0,17 \\
\hline Інтегральний показник фінансової безпеки & 0,42 & 0,37 & 0,44 & 0,50 & 0,51 \\
\hline
\end{tabular}

Джерело: $[5 ; 12 ; 15 ; 16]$ 
Щодо інших складових частин фінансової безпеки, а саме грошово-кредитної і валютної, необхідно констатувати, що грошово-кредитна безпека головним чином залежить від ефективності банківської діяльності, реалізації бюджетноподаткової та боргової політики, чинників інституціонального характеру тощо. Інтегральний показник грошово-кредитної безпеки протягом 2014-2018 рр. знаходився на дуже низькому рівні, а у 2015 році - небезпечному.

Аналізуючи дані інтегрального показника валютної безпеки за 2014-2016 pр., можемо стверджувати про ï загрозливий стан, а період 2017-2018 pp. характеризує стан валютної безпеки на незадовільному рівні. На стан валютної безпеки безпосередньо впливали наявність валютної заборгованості (боргів держави і суб'єктів господарювання країни в іноземній валюті) та ії розмір, а також розмір позовних претензій іноземних компаній до України і вимоги обов'язкового продажу валютних надходжень до країни.

Результати розрахованого рівня боргової безпеки України показують, що стан боргової безпеки, хоча і має позитивну тенденцію до покращення, все ж таки на кінець 2018 року характеризується як критичний. Катастрофічним рівнем виділяємо період 2014-2015 рр., оскільки в цей період в Україні збільшилися запозичення, щоб профінансувати поточні видатки на фоні скорочення доходів, а також зріс борг щодо ВВП через девальвацію курсу національної валюти, яка є результатом кризи.

Проаналізувавши результати сформованих інтегральних індикаторів окремих елементів фінансової безпеки України, нами був розрахований загальний індикатор фінансової безпеки. Як показують дані табл. 1, інтегральний показник фінансової безпеки у 2014 році становив 0,42 і починаючи 32014 року мав тенденцію до зниження. Критичного стану цей показник досяг у 2015 році, коли його значення становило 0,37 , що на 0,05 менше показника 2014 року. Це пояснюється наявністю як внутрішніх, так і зовнішніх загроз фінансовій системі України, що призвело до погіршення фінансової безпеки країни. Проте станом на 31.12.2018 р. значення інтегрального показника фінансової безпеки підвищилося на 0,14 до значення 0,51 , що означає поступове покращення фінансової безпеки України.

Отже, наведені розрахунки підтверджують результати методичних рекомендацій Міністерства економічного розвитку і торгівлі України та переконують у тому, що рівень фінансової безпеки України є небезпечним. Найбільшими загрозами при цьому $є$ незбалансованість бюджетної системи, збільшення зовнішнього боргу, високі темпи інфляційних процесів, зберігання значної частки тіньової економіки, умов для корупції $\mathrm{i}$ криміналізації фінансових відносин та інше.
В умовах значної кількості глобальних викликів, загроз і ризиків постає необхідність попередження загроз фінансовій безпеці України. Цього можна досягнути шляхом удосконалення науковометодичних засад оцінювання рівня фінансової безпеки держави 3 урахуванням взаємозв'язків фінансової безпеки з іншими складниками економічної безпеки, формування комплексу заходів превентивного характеру тощо. Тому назвемо шляхи вдосконалення методичних підходів до оцінювання рівня фінансової безпеки України.

Аналіз наукових позицій про склад індикаторів фінансової безпеки, проведений авторами, дав змогу визначити відсутність показників фінансової поведінки домогосподарств у структурі таких індикаторів. Нову групу індикаторів фінансової безпеки - індикатори, що відображають заощадження населення та його операції на кредитному і валютному ринках, - слід віднести до групи специфічних індикаторів, що зумовлено системою принципів відбору індикаторів фінансовоїбезпеки.

Відбір індикаторів, що відображають заощадження населення та його операції на кредитному i валютному ринках, опирається на пропозиції авторів щодо розвитку методичних підходів до індикативної оцінки фінансовоїбезпеки, а також на результати емпіричного аналізу зміни рівня добробуту, характеру і структури заощаджень та операцій населення на валютному і кредитному ринках.

Із групи індикаторів фінансової стійкості [2], що розраховуються Міжнародним валютним фондом, 3 метою нашого аналізу необхідно вибрати групу індикаторів «Financial Soundness Indicators for Households», що відображають заощадження населення та його операції на фінансовому ринку. Всі індикатори цієї групи відповідають цілям нашого дослідження:

- Household debt to gross domestic product;

- Household debt service and principal payments to income;

- Household debt to household disposable income.

Отже, додаючи до індикаторів стану фінансової безпеки України запропоновані нами індикатори, що відображають заощадження населення та його операції на кредитному і валютному ринках, маємо такий вигляд кожного елемента фінансової безпеки України за 2018 рік (табл. 2).

Відповідно до таблиці 2 бачимо, що в 2018 р. розрахунковий інтегральний показник фінансової безпеки України є на незадовільному рівні (52\%), зокрема, є можливість і подальшого підвищення рівня фінансової безпеки. Запропоновані до розрахунку індикатори ризиків фінансової поведінки населення значно вплинули на банківську, валютну і грошово-кредитну безпеку. Це пояснюється впливом економічних, соціальних та психологічних факторів на формування заощаджень, поведінку населення на кредитному, валютному i 


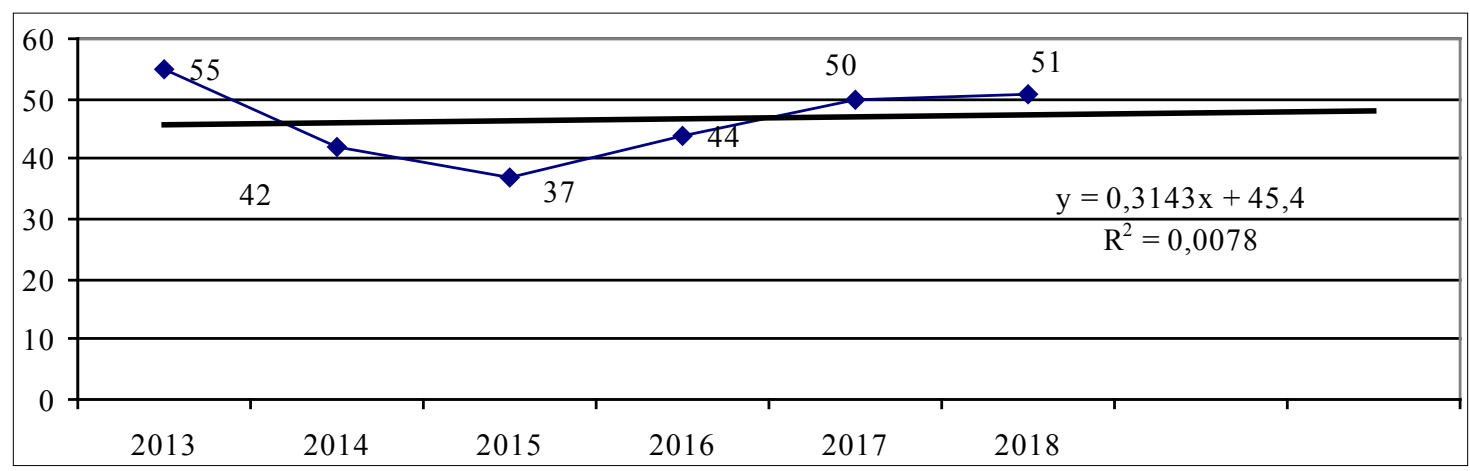

Рисунок 1 - Рівень фінансової безпеки України у 2013-2018 рр. та лінія тренду

фондовому ринках, а також інші інклюзії та фінансову грамотність населення. Водночас визначити чутливість представлених в таблиці 2 індикаторів до макроекономічних шоків, тобто їхню здатність попереджати про можливі загрози фінансовій безпеці, можливолише в результаті емпіричноїоцінки.

У проведеному дослідженні були використані статистичні дані показників фінансової безпеки України за 2014-2018 рр. У ці періоди в Україні спостерігалася негативна динаміка за багатьма показниками, які характеризують фінансову безпеку країни. Отже, під час прогнозування рівня фінансової безпеки України скористаємося методикою виявлення основної тенденції (тренду) ряду. Вихідні дані для прогнозування наведені у таблиці 3.

Далі визначимо параметри рівняння прямої: $\mathrm{a}_{0}=279 / 6=46,5 ; \mathrm{a}_{1}=11 / 28=0,39$. Таким чином,

Таблиця 2 - Стан інтегральних показників складників фінансової безпеки України з урахуванням індикаторів ризиків фінансової поведінки населення за 2018 р. [5; 12; 15; 16]

\begin{tabular}{|l|l|l|}
\hline \multicolumn{1}{|c|}{ Інтегральний індикатор } & \multicolumn{1}{|c|}{ Значення індикатора } & \multicolumn{1}{c|}{ Стан індикатора } \\
\hline Банківська безпека & 0,40 & небезпечний \\
\hline Безпека небанківського фінансового ринку & 0,32 & небезпечний \\
\hline Бюджетна безпека & 0,65 & задовільний \\
\hline Грошово-кредитна безпека & 0,57 & незадовільний \\
\hline Валютна безпека & 0,44 & незадовільний \\
\hline Боргова безпека & 0,20 & незадовільний \\
\hline Інтегральний показник фінансової безпеки & 0,52 & незадовільний \\
\hline
\end{tabular}

Джерело: $[5 ; 12 ; 15 ; 16]$

Таблиця 3 - Розрахунок параметрів рівняння прямої динамічного ряду рівня фінансової безпеки України у 2013-2018 рр

\begin{tabular}{|c|c|c|c|c|c|c|c|}
\hline Роки & $\begin{array}{c}\text { Рівень } \\
\text { фінансової } \\
\text { безпеки }\left(y_{\mathrm{i}}\right)\end{array}$ & $\begin{array}{c}\text { Умовне } \\
\text { позначення } \\
\text { періодів }\left(t_{i}\right)\end{array}$ & $\mathbf{y}_{\mathrm{i}} \times \mathbf{t}_{\mathrm{i}}$ & $t_{i}{ }^{2}$ & $\begin{array}{c}\text { Вирівняне } \\
\text { рівняння ряду } \\
\text { динаміки } \hat{\mathbf{y}}_{t}\end{array}$ & $\mathbf{y}_{t}-\hat{y}_{t}$ & $\left(y_{t}-\hat{y}_{t}\right)^{2}$ \\
\hline 2013 & 55 & -3 & -165 & 9 & 45,33 & 9.67 & 93,5089 \\
\hline 2014 & 42 & -2 & -84 & 4 & 45,72 & $-3,72$ & 13,8384 \\
\hline 2015 & 37 & -1 & -37 & 1 & 46,11 & -9.11 & 82.9921 \\
\hline 2016 & 44 & 1 & 44 & 1 & 46,89 & $-2,89$ & 8,3521 \\
\hline 2017 & 50 & 2 & 100 & 4 & 47,28 & 2,72 & 7,3984 \\
\hline 2018 & 51 & 3 & 153 & 9 & 47,67 & 3,33 & 11,0889 \\
\hline Разом & 279 & 0 & 11 & 28 & 279 & 0 & 217.1788 \\
\hline
\end{tabular}

Джерело: розраховано авторами

Таблиця 4 - Прогноз рівня фінансової безпеки України на 2019-2021 рр.

\begin{tabular}{|l|l|l|l|}
\hline \multirow{2}{*}{ Роки } & \multicolumn{3}{|c|}{ Сценарій прогнозу } \\
\cline { 2 - 4 } & \multicolumn{1}{|c|}{ песимістичний } & \multicolumn{1}{c|}{ оайбільш імовірний } & оптістичний \\
\hline 2019 & 42,81 & 48,84 & 54,87 \\
\hline 2020 & 43,20 & 49,23 & 55,26 \\
\hline 2021 & 43,59 & 49,62 & 55,65 \\
\hline
\end{tabular}


рівняння прямої ряду динаміки, що характеризує рівень фінансової безпеки України, має такий вигляд: $\mathrm{y}_{\mathrm{t}}=46,5+0,39 \mathrm{t}$, тобто середній рівень фінансової безпеки становить 46,5\%, середньорічний приріст - 0,39\%. Використовуючи виведене рівняння, визначимо прогноз на 2019-2020 роки. Тобто за $\mathrm{t}=6$ рівень відкритості економіки становитиме: $46,5+0,39 \times 6=48,84$. Визначимо динаміку рівня фінансової безпеки України у 2013-2018 роках та продемонструємо лінію тренду на рис. 1.

Таким чином, багатовимірний коефіцієнт кореляції (множинний R) визначає силу лінійної залежності, яка існує між двома змінними у разі однофакторної моделі регресії або характеризує кореляцію між залежною змінною Y і прогнозом $\hat{Y}$ для багатовимірних моделей регресії.

Наприкінці дослідження здійснимо прогноз рівня фінансової безпеки України на 2019-2021 роки (табл. 4).

Отже, прогноз рівня фінансової безпеки України на 2020 рік матиме такий вигляд: за оптимістичним сценарієм рівень бюджетної безпеки становитиме $55,26 \%$, за песимістичним сценарієм - 43,20\%, за найбільш імовірним - 49,23\%. Аналогічним чином проведемо розрахунки на 2019 та 2021 рр. Характеризуючи отримані результати прогнозування на період 2019-2021 рр., слід відзначити позитивні тенденції щодо підвищення рівня фінансової безпеки України.

Висновки. Наші дослідження доводять необхідність удосконалення науково-методичних засад оцінки фінансової безпеки України в контексті глобалізаційних викликів. Комплексність у побудові системи індикаторів, що виявлена нами як один 3 елементів загальновизнаного ядра методичного підходу в дослідженні фінансової безпеки, реалізується у взаємопов'язаному оцінюванні таких систем: дворівневої системи індикаторів фінансової безпеки; системи принципів відбору даних індикаторів; системи критеріїв класифікації даних індикаторів; моніторинг індикаторів з метою оцінювання рівня фінансової безпеки. Також установлено, що глобалізаційні процеси зачіпають усі складники фінансової безпеки держави, створюючи загрози для розвитку національної економіки.

Проведений аналіз методичних підходів до визначення порогових значень індикаторів фінансової безпеки дав змогу констатувати, що порогові значення можуть мати один із трьох рівнів оцінювання: мінімально допустимий, максимально допустимий та відхилення від середнього значення за період. Водночас зберігаються методичні проблеми щодо порогових значень індикаторів фінансової безпеки держави, зокрема вибірковість і відміни в методичному обгрунтуванні критеріїв та їхніх порогових значень.

Досліджені методичні підходи до оцінювання фінансової безпеки i 3'ясування наявної актуальності дослідження, дали змогу сформувати певні напрями вдосконалення процесу оцінювання фінансової безпеки України в умовах глобалізації фінансових ринків, а саме: застосування індикатора фінансової поведінки населення на кредитному і валютному ринках під час оцінюванні таких складників фінансової безпеки, як банківський, валютний та грошово-кредитний; впровадження принципів відкритості і гнучкості в індикативному оцінюванні фінансової безпеки України; організація моніторингу змін у системі загроз та актуалізація їх оцінювання.

\section{Список використаних джерел:}

1. Державна казначейська служба України: Офіційний сайт. URL: https://www.treasury.gov.ua/ua (дата звернення: 22.03.2020).

2. Financial Soundness Indicators and IMF. The official website of the International Monetary Fund.URL:https://www.imf.org/ external/np/sta/fsi/eng/fsi.htm (дата звернення: 19.02.2020).

3. Hacker J. Standing on shaky Ground: Americans' experiences with economic insecurity [Electronic resource] / J. Hacker, Ph. Rehm, M. Schlesinger. Economic Security Index. Washington: The Rockefeller Foundation, 2010. 36 p. URL: http://voices.washingtonpost.com/ezraklein/ESI\%20report\%20 embargo.pdf.

4. Гудзовата О.О. Програмування політики функціонування грошово-кредитного сектору в системі фінансової безпеки держави. Глобальні та національні проблеми економіки: електрон. наук. фахове вид. 2018. Вип. 21. С. $577-582$. URL: http://global-national.in.ua/archive/21-2018/110.pdf.

5. Інформаційно-аналітичні матеріали за 2014-2018 роки: Офіційний сайт Міністерства економічного розвитку і торгівлі. URL: http://www.me.gov.ua/control/uk/publish/category/main?cat (дата звернення: 18.02.2020).

6. Калюжна Н. Г., Барон І.Г. Трансформація методичних підходів до оцінювання економічної безпеки України. Бізнес Інформ. 2018. № 11. С. 22-27.

7. Кулінська А.В. Концептуальні засади розробки системи державного управління фінансовою складовою економічної безпеки економіки України. Ефективна економіка: електрон. журн. 2017. №2. URL: http://dspace.opu.ua/jspui/ handle/123456789/9646.

8. Кузенко О.Л. Фінансові відносини в системі фінансової безпеки суб'єктів господарювання. Економіка і регіон. 2015. № 3. C. 110-115.

9. Мелих О. Фінансова безпека держави: сутність, критерії оцінки та превентивні заходи зміцнення. Економічний аналіз. 2013. Вип. 12. Ч. 2. С. 266-272.

10. Мирончук В.М., Паночишин Ю.М. Оцінка рівня фінансової безпеки в Україні. Науковий вісник Ужгородського національного університету. Серія: Міжнародні економічні відносини та світове господарство. 2017. Вип. 13(2). С. 31-34. 
11. Про затвердження Методичних рекомендацій щодо розрахунку рівня економічної безпеки України: Наказ Міністерства економічного розвитку і торгівлі України від 29.10.2013 p. №1277. URL: https://zakon.rada.gov.ua/rada/ show/v1277731-13 (дата звернення: 13.04.2020).

12. Огляд економіки України. Бюлетень НБУ за 2014-2018 роки. URL: http://www.bank.gov.ua/control/uk/publish/ category?cat_id=58127 (дата звернення: 22.04.2020).

13. Основи світової економіки. URL: http://gx3000.ru/osnovi-svitovoiekonomiki/najvazhlivishi-ekonomichni-pokaznikirozvitku.html (дата звернення: 19.04.2020).

14. Рекуненко I.І., Бочкарьова Т.О., Кононенко С.В. Оцінка рівня фінансової безпеки України. Причорноморські економічні студіï. 2019. Вип. 40. С. 211-216.

15. Статистична інформація за 2014-2018 роки: Офіційний сайт Державної служби статистики України. URL: http://www.ukrstat.gov.ua (дата звернення: 19.02.2020).

16. Статистичні звіти за 2014-2018 роки: Офіційний сайт Державної фінансової інспекції України. URL: http:/www.dkrs.gov.ua/kru/uk/publish/category/52428 (дата звернення: 19.02.2020).

17. Вареник В.М. Аналіз методик розрахунку економічної безпеки України. Академічний огляд. 2016. № 1. С. 70-79.

18. Винниченко Н.В., Есманов. О.М. Оцінка стану фінансової безпеки в Україні. Економічний часопис - XXI. 2014. №3-4(2). C. 47-51.

\section{References:}

1. State Treasury Service of Ukraine: The official website. URL: https://www.treasury.gov.ua/ua (accessed 22 February 2020).

2. Financial Soundness Indicators and IMF: The official website of the International Monetary Fund. URL: https://www.imf.org/external/np/sta/fsi/eng/fsi.htm (accessed 19 February 2020).

3. Hacker, J. Rehm, Ph. Schlesinger M. (2010). Standing on shaky Ground: Americans' experiences with economic insecurity. Economic Security Index. Washington: The Rockefeller Foundation. URL: http://voices.washingtonpost.com/ezraklein/ ESI\%20report\%20embargo.pdf.74.

4. Hudzovata, O.O. (2018). Programming of monetary policy functioning of the monetary sector in the system of financial security of the state. Global and national problems of economy, 21, 577-582. URL: http://globalnational.in.ua/issue-21-2018.

5. Information and analytical materials for 2014-2018 years. URL: http://www.me.gov.ua/control/uk/publish/category/ main?cat.28 (accessed 18 February 2020).

6. Kaliuzhna, N.H. Baron, I.H. (2018). Transformation of methodological approaches to assessing the economic security of Ukraine. Business-Inform. 11, 225-227.

7. Kulinska, A.V. (2017). Conceptual principles of development of the system of state management of the financial component of economic security of the Ukrainian economy. Effective Economics. 2. URL: http://dspace.opu.ua/jspui/handle/123456789/9646.

8. Kuzenko, O.L. (2015). Financial relations in the financial security system of economic entities. Economy and region, $3,110-115$.

9. Melykh, O. (2013). State financial security: nature, evaluation criteria and preventive measures of strengthening. Economic analysis, 12 (2), 266-272.

10. Myronchuk, V.M. Panochyshyn, Yu.M. (2017). Estimation of the level of financial security in Ukraine. Scientific Bulletin of Uzhgorod National University, 13(2), 31-34.

11. Про затвердження Методичних рекомендацій щодо розрахунку рівня економічної безпеки України: Наказ Міністерства економічного розвитку і торгівлі України від 29.10.2013 p. №1277. URL: https://zakon.rada.gov.ua/rada/ show/v1277731-13 (accessed 13 February 2020).

12. Economic Review of Ukraine. NBU Bulletin for 2014-2018. URL: http://www.bank.gov.ua/control/uk/publish/category?cat id $=58127$ (accessed 22 February 2020 ).

13. Fundamentals of the World Economy. URL: http://gx3000.ru/osnovi-svitovoiekonomiki/najvazhlivishi-ekonomichni-pokazniki-rozvitku.html (accessed 19 February 2020).

14. Rekunenko, I.I. Bochkarova, T.O. Kononenko S.V. (2019). Assessment of the financial security level of Ukraine. Black Sea Economic Studies, 40, 211-216.

15. Statistical information for 2014-2018 years: The official website State and Statistics Service of Ukraine. URL: http://www.ukrstat.gov.ua (accessed 19 February 2020).

16. Statistical Report for 2014-2018 years: The official website State Financial Inspectorate of Ukraine. URL: http://www.dkrs.gov.ua/kru/uk/publish/category/52428. (accessed 19 February 2020).

17. Varenyk, V.M. (2016). A list of methods of calculating the economic security of Ukraine. Academic Review, 1(44), 70-79.

18. Vynnychenko, N.V. Esmanov, O.M. (2014). Assessment of financial security in Ukraine. Economic Journal - XXI, 3-4(2), 47-51. 
Kotkovskyi Volodymyr, Drobchak Alla, Leskova-Hodlevska Yulia

Kryvyi Rih Faculty of the National University of Odesa Law Academy

\section{EVALUATION OF THE FINANCIAL SECURITY LEVEL OF UKRAINE IN THE CONDITIONS OF FINANCIAL GLOBALIZATION}

The article is devoted to methodological aspects of evaluation level of financial security Ukraine in terms of financial globalization. The state of financial security of Ukraine was analyzed in the context of its key elements, including banking, budgetary, monetary, currency, debt security, as well as every security of the non-banking financial sector. There are several methodological approaches along on assessment of the financial security of Ukraine, namely Guidelines of the Ministry of Economic Development and Trade of Ukraine (2013), methodology on the Global Competitiveness Index, proposed by the World Economic Forum (1979), as well as Guidelines for experts of the National Institute of International Security of Ukraine (2003). The analysis of methodological approaches to determining the thresholds of financial security indicators has allowed to state that thresholds can have one of three levels of assessment: minimum permissible, maximum permissible and deviation from the average value for the period. At the same time, methodological problems regarding the thresholds of financial security indicators of the state, in particular selectivity and differences in methodological substantiation of criteria and their thresholds, remain. Taking into account the normalized values of indicators and their weighting coefficients, the article formed integral indicators of each element of financial security of Ukraine for 2014-2018, calculated the overall financial security indicator of Ukraine, and proved that as of December 31, 2018, the level of financial security of Ukraine was at a dangerous level. The authors of the scientific article described ways to improve methodological approaches to assessing the level of financial security of Ukraine, in particular, adding indicators and risks of financial behavior of the population related to the savings of the population and its operations in the credit and currency markets. The study made forecasting of financial security of Ukraine in 2020-2021 years using techniques and identify the main trends (trend) series and noted the positive trend to enhance the financial security of Ukraine. Also the article found that globalization processes affect all components of the financial security of the state, creating threats to the development of the national economy. The main directions for improving the process of assessing the financial security of Ukraine in the conditions of globalization of the financial markets include: the use of the indicator of the financial behavior of the population in the credit and currency markets in assessing such components of financial security as banking, currency and monetary; implementation of principles of openness and flexibility in the indicative assessment of financial security of Ukraine; organization of monitoring changes in the system of threats and updating of their assessment.

Key words: globalization, financial security, economic security, banking security, budgetary security, currency security, monetary security, debt security, non-bank financial sector security, integral indicator.

JEL classification: E60, E69, P43. 